\title{
EFFECT OF SNOW COVER ON TIME LAG OF RUNOFF FROM A WATERSHED
}

\author{
by
}

\author{
DaijI Kobayashi and Hideaki Motoyama
}

Institute of Low Temperature Science, Hokkaido University, Sapporo 060, Japan

\section{ABSTRACT}

A large scale study on the dependence of time lag of runoff on snow depth and stratigraphy was carried out in a watershed. The time lag in peak runoff was found to be increased by $1.5-4 \mathrm{~h}$ per $1 \mathrm{~m}$ increment in snow depth. Although the data were widely scattered, it was found that the time lag series converged in a line every year and that discrete layers in the snow cover composed in a warm winter, accelerated meltwater flow.

Subtracting the time of propagation through a snowcover from the total time lag, the effect of size of a watershed on a delay in runoff was rearranged, as follows:

$$
T_{f}=250 A^{0.17} R_{e}^{-0.5}
$$

where $T_{f}$ is the time lag in min after discharge from a snow cover, A the area of a watershed in $\mathrm{km}^{2}, \mathrm{R}_{e}$ the effective snowmelt in $\mathrm{mm} / \mathrm{hr}$. The time lag $\mathrm{T}_{f}$ increases only by 1.5 times when an area of a watershed is increased by a factor of ten.

\section{INTRODUCTION}

Accurate forecasting of a peak time in snowmelt runoff from a watershed is a prerequisite for controlling water flow at a hydraulic power plant and forestalling damage due to a snowmelt flood. Although several measurements have been made of the vertical flow of meltwater through a snowpack (Colbeck 1977), few studies have been pursued on the propagation of meltwater in a mountain snow cover on the scale of an entire watershed (Kobayashi 1981, Jordan 1983). Because the behaviour of meltwater in an inclined snow cover is too complicated to be dealt with by direct measurements, it has usually been investigated by analysing
hydrographs for the watershed.

Observations were carried out in the headwaters of the Uryu River $290-700 \mathrm{~m}$ above sea level located in the northern part of Hokkaido Island. Five adjacent experimental watersheds (area: $0.4,1.4,11.4,56.4$, and $108 \mathrm{~km}^{2}$ ) were selected, so that the runof delay was compared with each other. The third one was treated as the main watershed.

The region is one of the coldest areas in Japan, with the annual mean air temperature of only $3.5^{\circ} \mathrm{C}$. Peak seasonal snow accumulation ranges from 60 to 110 $\mathrm{cm}$ - water (1.5 - $2.7 \mathrm{~m}$ in depth). In the snowmelt period from mid-April to mid-May the air temperature ranges between $-5^{\circ} \mathrm{C}$ and $10^{\circ} \mathrm{C}$. The daily amount of snowmelt ranges from 1 to $4 \mathrm{~cm}$ - water and the specific runoff from 0.20 to $0.6 \mathrm{~m}^{3} / \mathrm{s} \cdot \mathrm{km}^{2}$. There is no significant difference in the amount of snowmelt between the mountainous district and the lower land.

The cover is a thin forest with dense bamboo bush undergrowth and the surface soil is silt and clay. Tuffaceous siltstone and sandstone underlie the region at the shallow depth. The inclination of the surface slope averages $20-25 \%$.
DEPENDENCE OF TIME LAG RUNOFF ON DEPTH AND HYDRAULIC PROPERTIES OF SNOW COVER

The runoff gives the diurnal periodic wave, which shows the minimum rate before noon and the peak in the evening, while the peak snowmelt occurs nearly at noon when the solar radiation is at its maximum. As the snow depth decreases, the daily peak of hydrograph arrives earlier. Time lag in snowmelt runoff is defined in this study by a difference between peak times in snowmelt and in runoff.

The time lag on the main watershed $\left(11.4 \mathrm{~km}^{2}\right)$ was plotted against the snow depth at the outlet of the watershed during past 11 snowmelt seasons as shown in Figure 1. Because the speed of water movement in the snow cover, soil or stream channel depended greatly on the amount of moving water, the plotted data were restricted to runoff of $0.2-0.5 \mathrm{~m}^{3} \cdot \mathrm{s}^{-1} \mathrm{~km}^{-2}$.

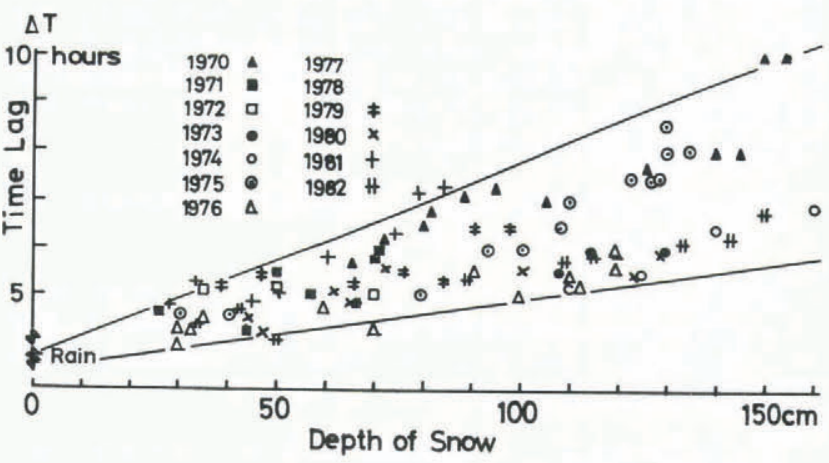

Fig.1. Time lag in peak runoff against snow depth at the outlet of a watershed.

The time lag in runoff was found to be elongated by 1.5 to $4 \mathrm{~h}$ every $1 \mathrm{~m}$ increment in depth of snow cover. Thus, the propagation speed of the wave of meltwater in the snow cover in the entire watershed was estimated to be $25-60 \mathrm{~cm} \cdot \mathrm{h}^{-1}$ obtained directly in homogeneous granular snowpacks (Kobayashi 1973).

Although the data were widely scattered, the time lag series converged in a line every year, which shows a linear relation between delay in runof $f$ and snow depth. This fact suggests the possibility of forecasting runoff delay based on hydraulic characteristic of the year's snow cover.

In the inclined snow cover on the mountain slope, surface meltwater percolates vertically in the homogeneous layer until it reaches the discrete layer which arrests and concentrates water flow and discharges it as a quick down-slope flow. Down-slope flow sometimes leaks vertically mainly through drainage channels until it is re-routed by an underlying discrete layer. Concentrated meltwater moves at the speed more than ten times that of dispersed water in the homogeneous snow layer (Fujino 1971). 

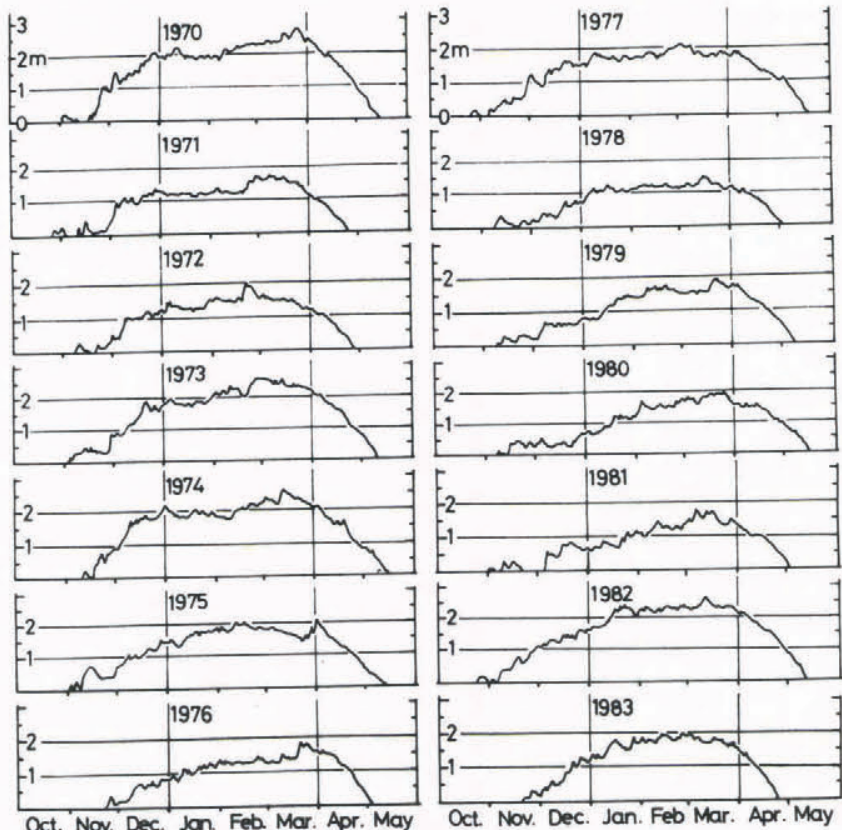

Oct. Nov. Dec. Jan. Feb Mar. Apr. May

Fig.2. Snow accumulation process (after Koyama and others, Uryu Experimental Forest of Hokkaido University).

Thus the hydraulic property of the snow cover varies greatly with the existence of the layered structure, which is highly variable from year to year. The snow accumulation process and winter climate contribute to the layering of the snow cover. Figure 2 shows the snow accumulation process in the past 14 seasons (after Koyama and others, Uryu Experimental Forest, Hokkaido University). The peak snow depth and warm climate bringing about melt metamorphism of the snow cover in mid-winter are classified and compared with the extent of runoff delay in Table 1, where the classifications are as follows:

1) Peak snow depth $-\mathrm{A}:>2.2 \mathrm{~m}, \mathrm{~B}$ : between $2.2-1.8 \mathrm{~m}, \mathrm{C}:<1.8 \mathrm{~m}$;

2) Mid-winter climate number of days when the maximum temperature exceeds $0^{\circ} \mathrm{C}$ in January and February $\mathrm{A}:>6$ days, $\mathrm{B}$ : between $3-5$ days, $\mathrm{C}:<2$ days;

3) Runoff delay lag-time A snow in depth, B : between $2.2-3.5 \mathrm{~h} \cdot \mathrm{m}^{-1}, \mathrm{C}$ : $>3.5 \mathrm{~h} \cdot \mathrm{m}^{-1}$

Table 1 shows that in the snowmelt periods of 1973 and 1982, following the warm winter with much

TABLE 1. RELATIONSHIP OF TIME LAG TO WINTER CLIMATE AND SNOW ACCUMULATION

$\begin{array}{cccc}\text { Year } & \begin{array}{c}\text { Snow } \\ \text { Depth }\end{array} & \begin{array}{c}\text { Warm } \\ \text { Climate }\end{array} & \begin{array}{c}\text { Runo } \\ \text { Delay }\end{array} \\ 1970 & \text { A } & \text { B(C) } & \text { C } \\ 1971 & \text { C } & \text { C } & \text { C } \\ 1972 & \text { B } & \text { A } & \text { B } \\ 1973 & \text { A } & \text { A } & \text { A } \\ 1974 & \text { A } & \text { C(A) } & \text { A } \\ 1975 & \text { B } & \text { B } & \text { B } \\ 1976 & \text { B } & \text { A } & \text { A } \\ 1977 & \text { B } & \text { C } & - \\ 1978 & \text { C } & \text { C } & - \\ 1979 & \text { B } & \text { A } & \text { B } \\ 1980 & \text { B } & \text { B } & \text { A } \\ 1981 & \text { C } & \text { C } & \text { C } \\ 1982 & \text { A } & \text { A } & \text { A }\end{array}$

snow, the wave of meltwater propagated at a relatively high speed of $0.5-0.6 \mathrm{~m} \cdot \mathrm{h}^{-1}$, because concentrated water moved quickly in the snow cover composed of discrete layers made by melt metamorphism. In the winter with much snow, the lower part of snow cover experiences melt metamorphism because of the warm climate in early winter and in addition in warm winter the middle and upper parts of the snow cover also experience melt metamorphism, by the occasional warm climate.

In the melt period of 1974 with much snow, runoff delay was also small because of the warm climate in early and late winter. On the contrary, in the melt period of 1970, runoff delay was large because of the cold climate and much snowfall in late winter.

On the other hand, in the melt periods of 1971 and 1981 after cold winter with little snow, the wave of meltwater propagated at a low speed of $0.25-0.3 \mathrm{~m} \cdot \mathrm{h}^{-1}$ in the snow cover, because dispersed water moved in the homogeneous snow cover.

In the main watershed, time-lag after discharge from a snow cover was estimated to be $220 \mathrm{~min}$ by subtracting the propagation time through a snow cover from the total time lag. As the travel time of water in the main channel was found to be $80 \mathrm{~min}$ or more by the salt trace method, the response time of meltwater flowing down in the soil on the mountain slope to stream channels was estimated to be about $140 \mathrm{~min}$. It turned out that the propagation time of meltwater in the mountain snow cover $1 \mathrm{~m}$ in depth is almost of the same order as that in the soil of the mountain slope. It follows from the results that water movement through the snow cover constitutes one of the significant problems for the advance of snow hydrology.

\section{DEPENDENCE OF DELAY IN RUNOFF ON THE SIZE} OF WATERSHED

Delay in runoff was measured also in two adjacent watersheds with areas of 1.4 and $53.6 \mathrm{~km}^{2}$, and the results were compared with that in the main watershed $\left(11.4 \mathrm{~km}^{2}\right)$ in Figure 3. All watersheds were similar in snow conditions and snowmelt climate. The lines representing time lag against snow depth were linear and parallel to each other. A difference in time lag between them was about $1 \mathrm{~h}$ and the rate of delay per $1 \mathrm{~m}$ of snow depth was about $2 \mathrm{~h}$.

Subtracting the time of propagation through the snow cover from the total time lag, the effect of size of a watershed on a delay in runoff was rearranged as shown in Figure 4. Added to this figure were the data in another watershed $\left(108 \mathrm{~km}^{2}\right)$ in the same region obtained by Hokkaido Electric Power Company. Following Kadoya's formula (1976), developed for the case of a rain storm given in a dotted line in Figure 4, the practical formula was proposed as follows:

$$
T_{f}=250 A^{0.17} R_{e}^{-0.5}
$$

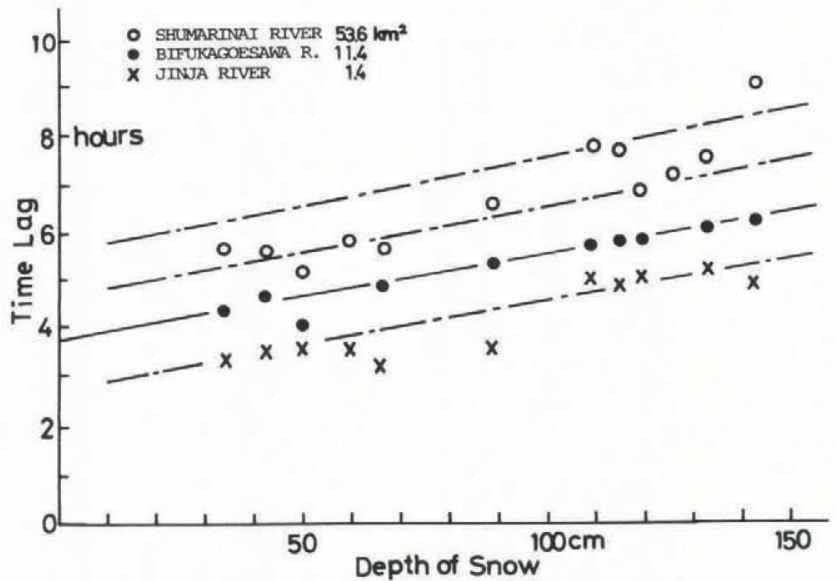

Fig.3. Time lag in peak runoff in 3 adjacent watersheds against snow depth. 


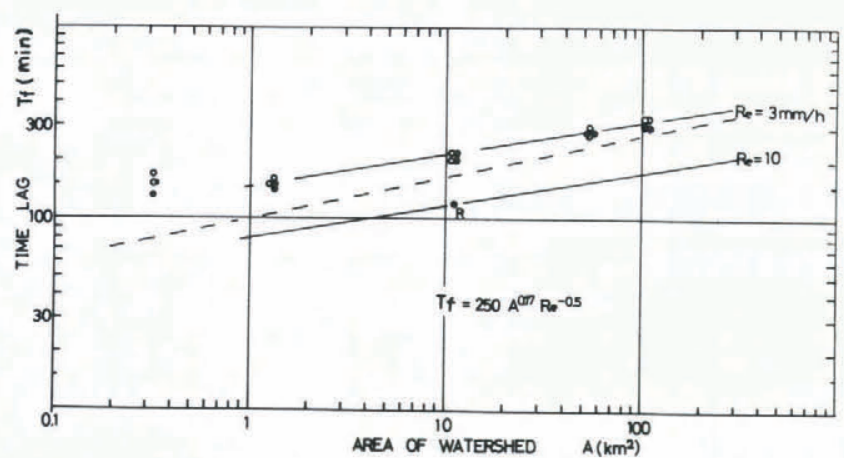

Fig.4. Time lag $T_{f}$ in peak runoff after discharge from a snow cover against area of watershed.

where $T_{f}$ : time lag in min after discharge from a snow cover; $A$ : area of a watershed in $\mathrm{km}^{2} ; \mathrm{R}_{e}$ : effective amount of snowmelt in $\mathrm{mm} \cdot \mathrm{h}^{-1}$. This equation is effective in the range of areas from 1 to $100 \mathrm{~km}^{2}$.

The result indicates that time lag $T_{\text {f }}$ is increased by only 1.5 times despite the fact that the main stream is lengthened by $3-4$ times when the area of a watershed is increased by 10 times. This nonlinear and quick response of a flood wave indicates that the main part of the meltwater discharges as a subsurface runoff, as was proved from the result of stream temperature analysis (Kobayashi 1981, 1985).

\section{REFERENCES}

Colbeck S C 1977 Short-term forecasting of water runoff. Journal of Glaciology 19(8): 571-588

Fujino K 1971 [Measurement of flow down speed of melt water in snow cover II]. Teion-Kagaku: [Low Temperature Science] A 29: 151-158

Kadoya M, Fukushima A 1976 [Concentration time of flood in small or medium river basin]. Kyodai Bosaikenkyujo Nenpo [Annals of Disaster Prevention Research Institute, Kyoto University] 19(B): 143-152

Kobayashi D 1973 [Flow-down speed of melt water in snow cover]. Teion-Kagaku [Low-Temperature Science] A 31: $135-142$

Kobayashi D 1981 [Time lag between centroid of snowmelt and the peak runoff rate I]. Teion-Kagaku [Low-Temperature Science] A 40: 61-66

Kobayashi D 1981 Separation of runoff components by stream temperature. Verhandlungen der International Vereinizung für Limnologie 21: 150-154

Kobayashi D 1985 Separation of snowmelt hydrograph by stream temperatures. Journal of Hydrology 76: $155-162$

Jordan P 1983 Meltwater movement in a deep snowpack. 1. Field observations. Water Resources Research 19(4): 971-978 